Cilt / Volume 3, Say1 / Issue 1, 2020, pp. 31-44

E - ISSN: 2636-7718

URL: https://ratingacademy.com.tr/ojs/index.php/arts/index

DOİ: https://doi.org/10.31566/arts.3.004

Araştırma Makalesi / Research Article

\title{
SANAT-SANATÇI VE BİR META NESNESİ OLARAK SANAT ESERİ
}

\author{
ART-ARTIST AND ART WORK AS A META OBJECT \\ Sedat BALKIR * \\ * Dr. Öğr. Üyesi, Mimar Sinan Güzel Sanatlar Üniversitesi, \\ TÜRKEY, e-mail: sbalkir63@gmail.com \\ ORCID ID: https://orcid.org/0000-0003-0960-3361 \\ Geliş Tarihi: 6 Ocak 2020; Kabul Tarihi: 30 Ocak 2020 \\ Received: 6 January 2020; Accepted:30 January 2020
}

\section{ÖZET}

Sanat ve sanatçı; çağlar boyunca insanın ilgi alanında olmuş, klişe tabirle mağara devrinden günümüze ve her alanda olmak üzere hiç eksilmeden etkisini sürdürmüştür. Güzel sanatlar, mimarlı, edebiyat ya da müzik dalında olsun, ortaya konan bu eserler; insanlık tarihini biçimlendirme konusunda yadsinamaz bir öneme sahiptirler.

Sanatın önemi konusunda hemfikir olsak da sanat nedir? nasll anlaşılır? veya neye hizmet eder? türü soruların cevabını vermek zordur. Sanatı tanımlama konusunda nerdeyse tamamen muğlak kriterler söz konusudur ve gerçekte, sanatın kendisi de bu belirsizliği kullandiğl için, olasılıkla böyle kalmaya da devam edecektir.

İdealist yaklaşım, sanatın maddi çıkarlara değil; yalnızca sanata hizmet etmesi gerektiğini iddia eder. Bu sebeple, 'halk için sanat', sanat olarak bile kabul edilmez. Sanatsal gelişim için, idealist tavrın yeterli olmadiğ herkes tarafindan bilinip kabul edilmesine karşın; 'sanat yoluyla kazanç elde etme' konusu gündeme geldiğinde, insanlar genellikle suskun kalmayı tercih ederler. Halbuki sanat eserinin paraya dönüşmesi, diğer her şey için olduğu gibi, sanat için de çok önemlidir. Bu makalede, etik olarak kabullenmekte zorlanıyor olsak da paranın, sanat ve sanatçının gelişimi üzerindeki etkisi ele alınmaya çalışılmışıtır.

Anahtar Kelimeler: Sanat, Sanatçı, Para, Esaret, Özgürlük

\section{ABSTRACT}

Art and artists have occupied a focal interest for people over the centuries, and this interest has had a continuous effect in every section of the society starting from prehistory. The artworks produced in areas of fine arts, architecture, literature, music, and performance arts, have an undeniable importance in shaping the human history.

Although we agree about the importance of art, it is difficult to find answers for such questions of 'what is art? 'How is it conceived?' or 'what does it contribute to?' Definition of art is mostly based on ambiguous criteria, and in reality, because artists make use of this ambiguity, it will probably continue to remain as it is. 
Idealist approach claims that art should only be serving art instead of financial interests. Therefore, 'art for the society' is not even accepted as art. Even though it is widely acknowledged that such an idealist attitude is not sufficient for the artistic development, when earning profit through art making is on the agenda, people usually prefer to keep quite. However, monetization of artworks is very crucial, as it is the case for everything else. In this article, although we may find it ethically challenging, the effect of monetary gains on the development of art and artists will be examined.

Key Words: Art, Artist, Money, Captivity, Freedom.

\section{GİRIŞ}

Sanatın ne olduğu ve nasıl anlaşılabileceğine dair tartışmalar yüzyıllardır insanların kafasını meşgul eden konulardan (Din, Tanrı ya da Varoluşsal Sorunlar gibi..!) biri olmuş ve neredeyse hiç bir dönem popüleritesini yitirmemiştir. İnsan üstü, hatta bir bakıma tanrı vergisi sayılabilecek özellikleri yardımıyla, 'Sıradan Ölümlüler'in asla ulaşamayacağı bir mertebede kalabilmeyi başarmış olan sanat, bu durumuna açıklama olabilecek gerekçelere de fazlasıyla sahiptir.

Sanatın neden bu kadar önemsendiğine dair süregelen belirsizlik, büyük oranda kendisine atfedilen kriterlerin karmaşık ve müphem yapısı ile ilgilidir. Ağzımızdan hiç düşürmediğimiz şekliyle, eğer sanatta bireyselliği ve özgünlüğü kabul ediyorsak, kişiden kişiye değişen kriterleri de peşinen kabul ediyoruz demektir. Bu karmaşanın, sanatın olmazsa olmaz koşullarından biri olduğu, bunun tersini düşünmenin ise; meselenin özüne aykırı olduğu gerçeği de her zaman göz önünde tutulmalıdır. Çağlar boyunca, farklı coğrafya, farklı kültür, farklı yaşam koşulları ve belki en önemli faktör olarak farklı insan yapıları sebebiyle oluşan çeşitlilik, hem sanatı hem sanatı tanımlama şekillerini de çok çeşitlendirmiştir.

\section{SANAT-SANATÇI VE BİR META NESNESI OLARAK SANAT ESERI}

Sanatla ilişki içinde olan insanlar (Sanatçı, Küratör, Eleştirmen, Tüccar, Koleksiyoner ya da Sanata İlgi Duyan) bu kaotik yapılanmayı oluşturan kişiler olmuşlardır. Kısa bir zaman aralığında değil, gerçekte binlerce yıllık bir süreçte oluşmuş bu kriterler, bazen bilinçli bazen de tam tersi olarak, hiç muhakeme edilmeksizin benimsenmiş, bu halleriyle nesilden nesile geçmiş ve muhafaza edilmeye çalışılmıştır. Genel olarak fikir birliğinde olunamayan ve neredeyse hiçbir şekilde formüle edilemeyen sanat, bu şekliyle, herkesin kendine münhasır yorumunu özgürce yapabileceği mükemmel bir malzeme olarak kullanılagelmiştir.

Yapılan çalışmanın bir sanat eseri olarak kabul edilme süreci ve bunun kıstaslarının ne olduğu konusu muhakkak ki çok daha ayrıntılı bir incelemeyi gerektirir. Ernst Fischer; "İnsan her zaman olabileceğinden ötede bir şey isteyecek, yaradılışının sınırlarını her zaman aşmaya çalışacak, her zaman ölümsüzlüğe kavuşmak için uğraşacaktır. Bu her şeyi bilme, her şeye üstün çıkma, her şeyi kavrama isteğini yitirdiği gün, insan da insan olmaktan çıkar artık. Bu yüzden, doğadan bütün gizleri ve kendisine üstünlük sağlayacak olanakları elde edebilmek için her zaman bilime gekeksinme duyacaktır. Yalnız kendi yaşayışında değil, hayal gücüyle daha denetim altına alamadığını sezdiği gerçekler karşısında yabancılık çekmemesi için de her zaman sanatın gerekli olduğunu unutmayacaktır" (Fischer, 1968, s. 239) diyerek insanın sanata niçin ilgi duyduğunu açıklamaya çalışır.

Bir çalışmanın sanat eseri olduğunu üreten kişi olarak, bizzat sanatçının kendisi mi söyler? Yoksa konuyla ilgili yakın çevresindeki sanatçı, eleştirmen, galerici, sanat izleyicisi ya da koleksiyoner gibi diğer kişiler mi bu kararı verirler? Burada, belirleyici pek çok etken (Eğitim, Mesleki Kariyer, Sosyal Çevre, Alıcı Tercihleri ve Şans faktörü!) sayılabilir. Muğlak yapısı sebebiyle, sanatı herkesin hemfikir olacağı bir şekilde tanımlamak neredeyse 
imkansızdır. Gerçekte bunun böyle olması yanlış da değildir çünkü sanat eseri olarak kabul edilmenin olmazsa olmaz birinci koşulu zaten ‘özgünlük’tür. Daha önce yapılmış olanlardan farklı ve mümkünse bir adım önde olmayı gerektiren bu koşul, öncelikle özgür bir ortamda çalışmayla ortaya çıkar. Herbert Read'in sanata dair görüşü şu şekildedir;

Sanat eseri, görmüş olduğumuz gibi bir insanın bilincinde aracısız olarak doğar, anlam kazanır, kuşkusuz bu arada toplumun ya da içinde yaşadığı dönemin genel kültürüyle bütünleşerek gelişir. Her artistik çözümde iki faktör vardır. Bunlardan biri kişinin arzuları, öteki toplumun istekleridir. Kişi becerebilirse, kendisi için bir sanat eseri yapabilir, bu mümkündür, fakat yarattığ 1 o şeyi kabul etmesi için toplumu ikna edebilirse bir sanat eserinin ortaya çıkarılmasından gelen tam doyumu elde etmiş olur. Ne var ki sıradan bir topluluk, sanat eserleri üzerinde bilinçli bir yargıda bulunabilecek bir durumda değildir, bir eseri kabul ya da reddederken bu işi halihazırdaki kültür faaliyetleri içinde yapmaktadır (Read, 1981, s. 104).

\section{SANAT NEDIR?}

Herkes sanat yapıtı üretebilir ve kendini sanatçı olarak gören herkes, mümkünse henüz hayatta iken, kendinde olduğuna inandığ tasdiklenme beklentisi içindedir. Sanat uğruna toplumu karşısına almış, uç noktada marjinal bir yaşam sürdüren ve üreten sanatçı tiplemelerinde bile bunun tersini iddia etmek zordur. Tavır olarak ister toplumun yanında ya da isterse tam karşısında konumlanmış bir görünümde olsun, bütün sanatçılar kendilerini ifade etme amacı içindedirler. Neresinden bakılırsa bakılsın, en basit haliyle "toplum tarafından benimsenme ihtiyacı" olarak görebileceğimiz bu durum gerçekte "topluma yaranma" çabasıdır. Sanatçıların, sanat dışında faaliyet gösteren diğer insanlara göre istisnai bir durum içinde oldukları kabul edilebilir ancak toplum etkisi ve toplumdan beklenti anlamında büyük farklar olduğunu düşünmek zordur.

Eserleri yeteri kadar ilgi görmemiş sanatçılar ise; pek tercih etmeseler de bu değerlendirmeyi gelecek kuşakların insafına bırakmak zorunda kalacaklardır. Ancak; kabul etmek gerekir ki, "Öldükten sonra meşhur olma" deyimi ütopik bir parodi olup; çalışmalarının karşılığını mümkünse yaşarken görmek isteyen insan doğasına da çok uygun düşmeyecektir.

"Sanat; bir karşılık beklemeden yapılmalıdır; aksi durumda ticarileşir, etki altına girer ve özgürlüğünü kaybeder" demek bir yanıyla doğru ve kulağa hoş gelen bir değerlendirme olabilir, ancak; tam olarak ayakları yere basmayan, biraz klişe ve ayni zamanda sanatçı üzerinde baskı da oluşturan bir çıkarımdır.

Herbert Read'in sanatçılar için söylediği şeyler, ilk bakışta biraz basit ama aslında oldukça gerçektirler. "Sanatçı son derece gürültülü olan içgüdüsel ihtiyaçları tarafindan dürtülmekte olan bir kişidir; onurlandırılmak, güçlü olmak, zengin ve ünlü olmak ve kadına aşık olmayı ister; fakat kendisini, bu hazları tatmaktan yoksun kılar. Böylece doyurulmayan herhangi bir arzu gibi, gerçeklikten yüz çevirir, bütün ilgilerini başka alanlara taşır, bütün libidosunu, arzularını bir fantazya hayat içinde yaratır" (Read, 1981, s. 108).

Ressam, heykeltraş ya da müzisyen olsun, isimlerini andığımızda yere göğe sığdıramadığımız birçok büyük sanatçının hayatlarını nasıl bir yoksulluk ve yoksunluk içinde geçirmiş olduklarını öğrendiğimizde sanatı sadece sanat için yaptıklarına inanmak da güçleşir. Hayatta olsun ya da olmasın 'Yarı Tanrı' mertebesine yerleştirdiğimiz o çok büyük sanatçıların, gerçekte sıradan beklentileri olan ve 'Sokaktaki Adam' diye tabir ettiğimiz insanlarla aynı şeylerin hayalini kurduklarını kabul etmemiz gerekiyor.

Hayatını rahat bir şekilde sürdürmeye yetecek miktarda bir gelir, mutlu bir aile ve onurlu bir hayat beklentisi bazı insanlar için çok klişe görünebilir ancak istisnalar kaideyi bozmaz ve bu durum sanatçılar için geçerlidir. Hangi konuda olursa olsun, çaba gösterilerek bir sonuç alınmışsa eğer; bunun karşılığını beklemek son derece doğaldır. Beklenti deyince de sadece 
parasal karşılık olarak düşünülmemeli; takdir edilme ve bu sayede oluşan tatmin duygusunun yaratacağı motivasyon açısından da değerlendirilmelidir. Ayrıcalıklı olma hissinin getirdiği özgüven, sanatçıyı çok daha istekli ve üretken hale getireceği için, çalışmaya ayrılan zaman ve buna bağlı olarak üretilen yapıt sayısı da artmış olacaktır. Sanatçının ustalaşması; yapıtlarını da olgunlaştıracak ve muhtemelen özgün yapıtlar oluşturabilmenin yolunu açan en önemli etken de bu olacaktır.

Donald Kuspit; "Her bir sanat eseri deyim yerindeyse sanatçının kendi kendisiyle karşılaşmasını, yani sanatçının malzemesi aracılığıyla duygularını yeniden yaşayıp, yeniden düzenlediği analitik bir seansı temsil eder. Her ne kadar sonuçta ortaya çıkacak şey sanat kı1ıfı altında kendini ifade etmekten, kendine ayna tutmaktan (yoksa kendi kendini taklit etmekten mi?) ibaret kalabilecek de olsa, atölye, sanatçının kendi kendini tedavi etmeye çalıştığı bir kliniğe dönüşür" (Kuspit, 2006, s. 31) derken sanat-sanat eseri-atölye ilişkisinin önemini vurgulamaya çalışır.

\section{SANAT, SANAT İÇİN Mİ, TOPLUM İÇİN MİDİR?}

Bazı kimseler; sanatçıların, sadece üretmeye odaklanmaları ve bunu yaparken, konsantrasyonlarını bozacak dış etkenlerden de kendilerini korumaları gerektiğini düşünürler. Adeta bir fanus içinde yaşamak ve üretmek olarak tanımlayabileceğimiz bu izole durum, bazı sanatçılar için ideal çalışma şekli de olabilir. 'Sanat, sanat içindir ve halk için yapılması durumunda sanat olma vasfinı kaybeder' diyenler, çoğunlukla bu gruba ait sanatçılardır.

Sanat eseri şüphesiz ki, sabırlı ve yoğun bir çalışma gerektiren bir süreçte ortaya çıkar. Kavramsal anlamda güçlü olmanın yanında; içerik, teknik ve ustalık olarak başarılı sonuçlar almak, herhalde bütün sanatçıların idealidir. Basit ve sıradan olan ne eseri oluşturan sanatçıyı ve ne de onu izleyenleri tatmin etmeyeceği için, zorluk derecesi yüksek yapıtlar istisnasız her dönem el üstünde tutulmuşlardır.

Sanat eserlerini; 'plastik fikir bağlamında orjinallik ve uygulamadaki ustalık' olarak ayrıcalıklı kılan değerleri düşündügüüüzde, kolayca üretilmiş ve ayni şekilde kolayca çözümlenerek, tüketilebilen yapıtların kimseyi heyecanlandırmayacağı açıktır. Herkese hitap ediyor olmak her sanatçının istediği şey olsa da herhalde hiç biri, kolayca anlaşılıyor olmayı arzu etmeyecektir. İzleyicinin dikkatini uzun süre boyunca üstünde tutmayı başaramamış; merak ve hayranlık oluşturmadan, hızlı bir şekilde bakılıp geçilen bir yapıt; şüphesiz ki sanatçı için gurur kaynağı değil, bir utanç vesilesi haline dönüşecektir. Norbert Lynton'ın sanat eserine bakış ve değerlendirmeye yönelik görüşü çarpıcıdır:

Sanatın en açık ve en zor yanı bir bakışta anlaşılıvermesidir. Bir kitabı, bir oyunu, bir şiiri, bir sonatı, bir pop şarkısını değerlendirmeden önce, kısa bir süre dikkatimizi onlara vermemiz gerekir. Oysa, bir anda yargılayıverdiğimiz sanat bir ömür boyu süren çabaların, hatta bir kuşağın emeklerinin sonucudur. Üstelik sanat eserlerinin bir bölümünü beğenip yücelterek, ötekileri 'bana hitap etmiyor' diye bir kenara bırakarak kendimizle övünebiliriz. Bazı sanat eserleri konuşur, bazıları bağırır; ancak en iyileri çok az soru sormayı ve çok fazla dinlemeyi gerektirir. Herseyden önce zor bir çalışmanın ürünüdürler ve bu nedenle hala güven uyandirabilirler (Lynton, 1982, s. 353).

'Sanat Toplum İçindir' diyen sanatçılar açısından sözkonusu kriterler biraz daha esnek olabilir. Çalışmalarını içinde yaşadığı toplumun verileri doğrultusunda; onların çıkarlarına yönelik ve yine onların anlayabileceği şekilde biçimlendiren sanatçıların çok yüksek ideallerden bahsetmesine zaten ihtiyaç da yoktur. Gerçekte bu sınırları, çok keskin hatlarla birbirlerinden ayırmak mümkün değildir. Toplum için ürettiğini söyleyen sanatçıları idealist olmamak ve kolaycılıkla suçlayamayacağımız gibi; 'Sanat Sanat İçindir' diyenleri, topluma arkasını dönmüş kişiler olarak nitelendirmek de doğru olmayacaktır. 
Ne kadar radikal veya anarşist görüşlere sahip olursa olsun; diğer insanlarla bir arada yaşamaya devam etmek isteyen kişiler, ancak onlar için üreterek o toplumun bir parçası olabilirler. Topluma dair olan her şey, istisnasız her dönem olmak üzere, her türden sanatsal amaca uyarlanmış ve kullanılagelmiştir. İster edebiyatçı ister ressam ya da heykeltraş olsun, bunların hepsine fazlasıyla yetecek malzeme her zaman bulunmuştur.

Konu "İnsan" olduğu sürece, ilham perisi yoksunluğu diye bir sorun da olmayacaktır. Sanatçılar içinde yaşadıkları toplumu malzeme olarak kullanırken, toplum için bir geri dönüşüm de sağlamış olurlar. Buradaki herhangi bir kopukluk, şüphesiz ki sanatçı için hayati derecede önemli kaynaklarından birini yitirmesi anlamına gelecektir.

\section{SANATIN İŞLEVI}

Tarih boyunca, sonu gelmeyen toplumsal olaylar, din olgusu, kendi varlığını sorgulama ya da içinde yaşadığı dünya ve evrenin gizemlerine dair olmak üzere, insanlığın çözemediği (Belki de hiçbir zaman çözemeyeceği!) sorunları hep olmuştur. Bunlar, ayni zamanda, bu sorunlara çözüm üretmeye çalışan insan gruplarını da oluşturmuş; büyücüler, din adamları, filozoflar, bilim insanları ve sanatçılar; binlerce yıldan beri, bu malzemeyi kullanarak toplumsal hayatı şekillendirme konusunda etkili olmuşlardır.

"Eski, modası geçmiş dinsel öğretiden doğan duyguları aktaran sanat; kilise düşüncelerine özgü sanat, vatanseverlik duygularını dile getiren sanat, cinsel duyguları içeren sanat, batıl inançlara dayalı korku, gurur, kibir, milli kahramanlara duyulan aşırı hayranlık duygusunu aktaran sanat, birinin kendi milletine duyduğu özel sevgiyi ya da şehvet duygusunu uyandıran sanat kötü ve zararlı olarak sayılacak, sansür edilecek ve kamuoyu tarafından hor görülecektir. Sadece bir grup insana ulaşabilen duyguları aktaran sanat, önemsiz olarak görülecek, ne suçlanacak ne de övülecektir. Genelde sanatın dağerlendirilmesi, bugün olduğu gibi ayrı, zengin bir sınıfın yetkisinde değil, bütün insanların yetkisinde olacaktır" (Tolstoy, 2000, s. 354). Tolstoy'un, yaklaşık 120 sene önce ve aslında başka bir olguyu anlatmaya çalışırken ortaya koyduğu ve sanatı besleyen kaynaklar olarak gördüğü etkenlerin günümüz koşullarında da hala geçerliliklerini koruyor olmaları ilginçtir. Bazı açılardan oldukça doğru bir saptama yapmış olsa da sanatın geleceğine yönelik tahmininde ayni başarıyı gösteremediği de rahatlıkla söylenebilir.

Fonksiyonel olan sanat dallarını bir tarafa koyarak sanatın işlevini sorguladığımızda; toplum için doğrudan bir fayda oluşturmak yerine, nerdeyse tamamen estetik hazzı tatmine yönelik bir amaç içinde olduğunu görebiliriz. Tabii ki bu saptama sanatın sadece estetik güzellik ve hoşluk peşinde koştuğu şeklinde algılanmamalıdır. Sanat, mağara devrinden günümüze, topluma bir şeyleri aktarmanın yolu olmuştur. Yazının olmadığı ya da varsa da okuyanın az olduğu dönemler için üstlendiği fonksiyon çok net ve belirleyicidir (Res. $1 \&$ Res. 2). İster büyü amaçl1, isterse dinsel, siyasal ya da toplumsal mesajlar vermeye yönelik olsun sanat en önemli ifade aracı olmuştur. Sadece haz vermeye yönelik değil; çirkinlik bayağıllk olarak değerlendirebileceğimiz şeyleri de malzeme olarak kullanmaktan çekinmemiş olan sanat, her türlü kaynaktan beslenmiş ve kendine has bir estetik dil oluşturmuştur. Sanat yoluyla aktarılan hikaye, olay, öğüt, propaganda ya da bir sanat kavramları, ayni zamanda sanatı da güçlendiren bir etki oluştururlar ancak şurası kesinlikle göz ardı edilmemelidir ki sanatta önemli olan ne anlatıldığı değil, nasıl bir sanat diliyle anlatıldığıdır. 
Resim 1: Lascaux mağarası M.Ö. 15.000

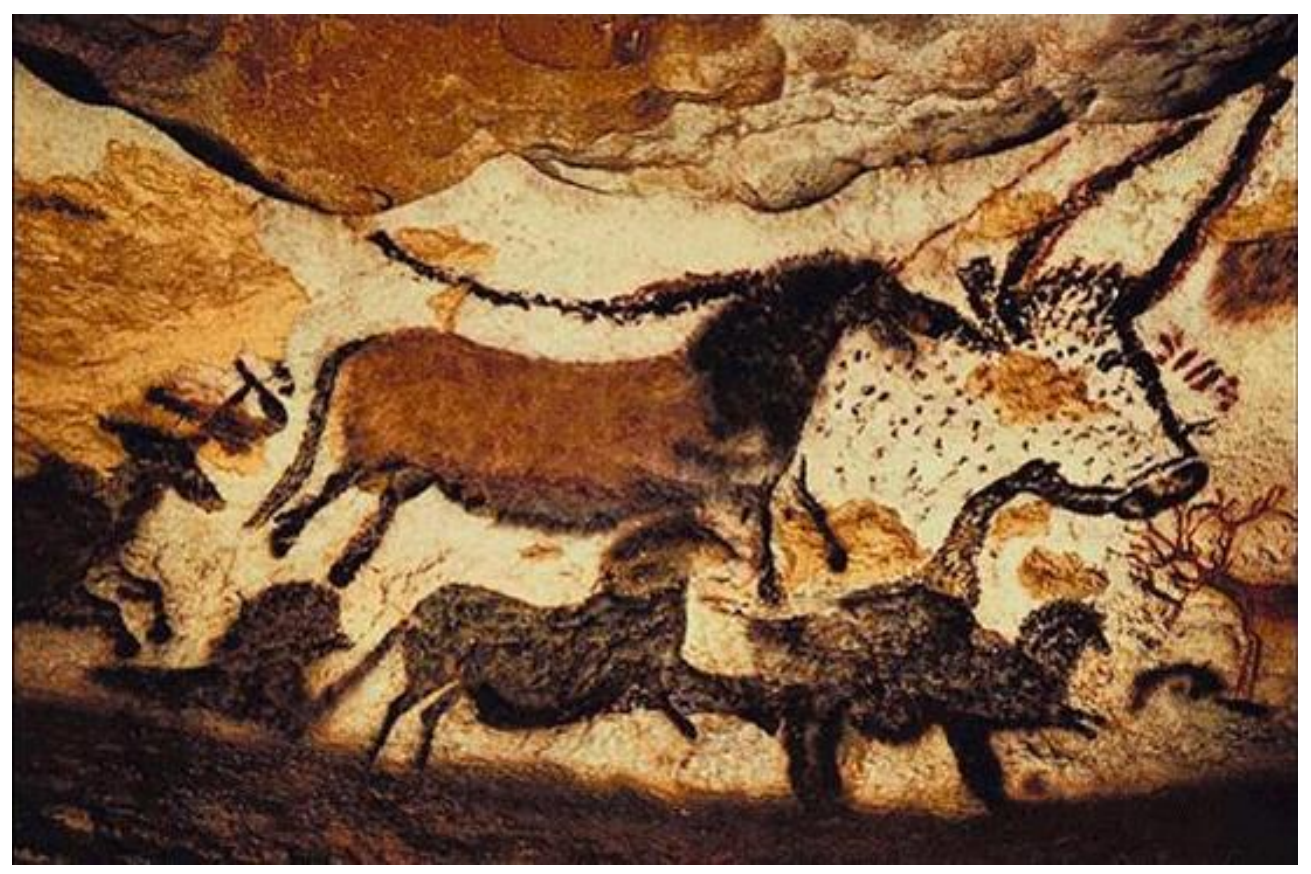

Resim 2: Kariye Müzesi, 14. Yy

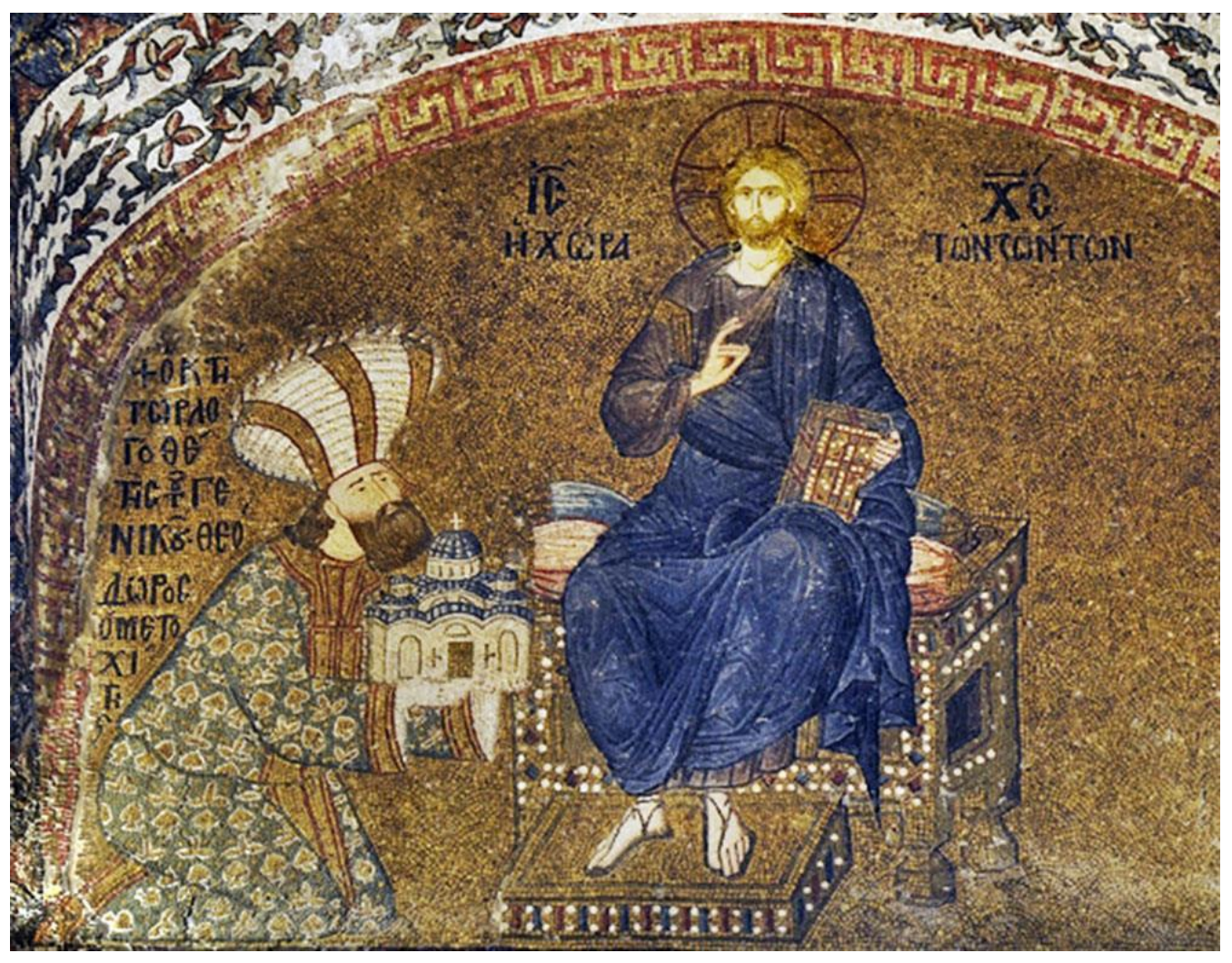




\section{SANATÇI KİMDİR?}

Bir sanatçıyı betimlemeye kalktığımızda genel olarak; marjinal, öncü, yerleşik değerler ve kalıplaşmış düşüncelerle barışık olmayan, her daim yenilik peşinde koşan, özgür ruhlu, isyankar, biraz anarşist, biraz da narsist olan ve standart kalıplara sokulamayacak türden insanlar akla gelir. Ne var ki, sanatçı olarak üstlendikleri misyon oldukça ağırdır ve biraz önce sıralanmış olan o fantastik özellikleri yanında, kendilerinden hem kontrollü hem de inandırıcı ve tutarlı bir sanatçı kişiliği beklenir. Sadece bunlar bile sanatçı özgürlüğünün lafta kalması için yeterli sebeptir ve biçimsel anlamda ne kadar özgün ya da marjinal olursa olsun; dikkat çekmeyi başarmış ve talep edilen bir sanatçı haline gelmişse eğer; kendisine şöhret sağlayan biçim anlayışını terkedip yeni arayışlara girmesi risk almak anlamına gelir. Çünkü bu durumun, hem eserlerine para yatırmayı düşünen koleksiyonerler ve hem de hayran kitlesi tarafından hoş karşılanmama olasılığı fazladır. Tamamen özgür yaratımı benimsemek bu kişiler tarafından refüze edilme tehlikesi barındırdığı için de bazı sanatçılar, 'Tutarlılık' söylemini 'Özgürlük' söyleminden daha çok tercih eder hale gelebilirler. Eserlerinin satılıyor olmasını, sanatçının özgürlüğünü kısıtlayıcı bir etken olarak görmek yanlış olmayabilir; ancak, çelişkili görünse de başka bir açıdan ele aldığımızda, sanatçıyı özgürleştiren bir yanı olduğunu da kabul etmemiz gerekir.

"Satış grafiği pek yüksek olmayıp (Hatta hiç!) üretmeye devam eden sanatçıların, ya parasal sorunları yoktur ya da ruhsal sorunları vardır" demek, çok yanlış olmaz. Buna en iyi örnek; hayatı büyük hayal kırıklıkları içinde geçen Vincent Van Gogh olabilir. Yaşadığı süreçte yalnızca bir resim satabilmiş (400 Frank-yaklaşık 1000 \$) sanatçı, yaşadığı hezeyanlara dayanamamış, 1890 yılında, henüz 37 yaşındayken intihar etmiştir. Hayatı yoksulluk içinde geçen Van Gogh'un ölümünün tam da yüzüncü yıldönümünde, "Dr. Gachet'nin Portresi” (Res. 3) adlı resminin, 82,5 milyon Amerikan Dolar'ına satılmış olması da bir hayli ironiktir. Van Gogh, eğer Dr. Gachet resminin o fiyata satıldı̆̆ını görmüş olsaydı, muhakkak ki şaşkınlığı çok büyük olurdu ancak asıl büyük şaşkınlığı; belki de dünyanın gelmiş geçmiş en çok tanınan ressamı olarak bizzat kendisinin gösterilmesi olduğunu farketmesi ile yaşamış olurdu.

Resim 3: Van Gogh, Dr. Gachet Portresi, 1890

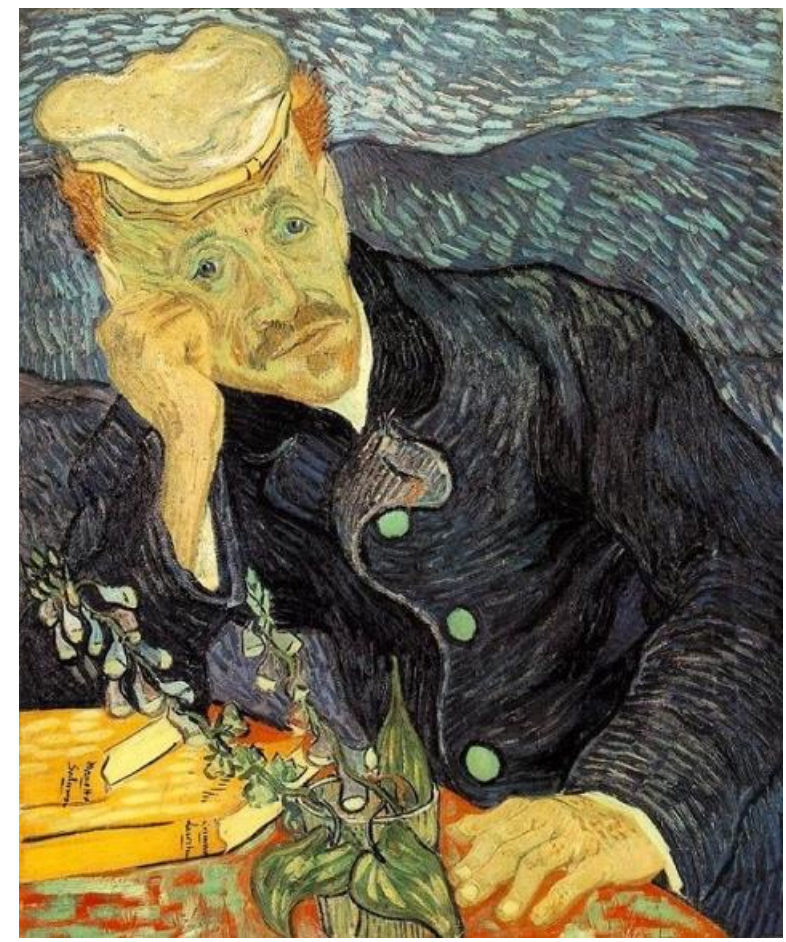


Donald Kuspit, Van Gogh'un içsel yapısı ve hassasiyetini aşağıdaki satırlarla tanımlarken; günümüz sanatının içinde bulunduğu duruma da açıklık getirmektedir:

Sanatın para haline geldiği bir dünyada gerçek sanat nedir? Gerçek sanatçı kimdir, tabii eğer sanatın ticari gerçekliğinden başka gerçeklik diye bir şey varsa? Tıpkı İsa'nın Tanrı'nın tapınağını tefecilerden arındırması gibi, Van Gogh da sanatın tapınağını tefecilerden arındırmak istemişti. Ne var ki günümüzde tefeciler sanat tapınağının sahipleri haline geldiler, ya da en azından bu tapınak onların ipoteği altına girdi (Kuspit, 2006, s. 168).

\section{SANAT EĞİTIMI GEREKLİ MIDİR?}

Sanat eğitimi ve dolayısıyla sanat eğitim kurumları, sanatın gelecek kuşaklara aktarımı konusunda yadsınamaz bir önemde olmalarına rağmen; bu kurumların aynı zamanda, sanatın "özgün olma" kriterleri için tehdit oluşturduğu ve hatta bunu tümden ortadan kaldırdığ yönünde görüşler de vardır.

Sanat Akademileri'nin tamamında geçerli olan eğitim, geçmiş dönem sanat ve sanatçılarına ait bilginin öğrenciye aktarılması ve sanatçı adaylarının, bu birikim 1şığında, güncel sanata dair çıkarımlarının değerlendirilmesi şeklinde olan yöntemdir. Sanatçı olmanın öğretilebilir bir şey olmadığını iddia edenler, yalnızca sanat akademileri dışındakiler olmayıp; bu konu söz konusu eğitim kurumlarında da tartışılan konulardandır. Başkalarının bilgi, üslup ve deneyimleri konusunda eğitim almış olarak sanat yapmaya soyunan kişilerin, kendilerini bu etkiden tamamiyle soyutlayarak, bütünüyle özgün bir şey ortaya koymaları mümkün değildir(!) şeklindeki iddia, kolayca reddedilebilecek bir olgu değildir.

Söz konusu eğitim kurumları Plastik sanatlar, müzik ya da edebiyat dallarında olsun; bir çok zaman bu tür eleştirilere maruz kalmışlardır. Örneğin Tolstoy'un 19. yüzyılda "Bu okulların öğretebilecekleri tek şey, başka sanatçıların yaşadıkları duyguları nasıl, hangi yolla aktarabildikleridir. Böyle bir eğitim, gerçek sanatın yayılmasına yardım etmediği gibi, sanatın taklitlerini arttırarak, insanları gerçek sanatı anlama gücünden yoksun bırakmaktan başka bir işe yaramaz" (Tolstoy, 2000, s. 265) ve "İnsanları sanata benzeyen şeylere alıştırmak, onları gerçek sanatı anlamaktan uzaklaştırmaktadır. Hiç kimse bu meslek okullarından geçen ve buralarda en büyük başarıyı kazanan insanlardan daha çok sanata kayıtsız değildir" (Tolstoy, 2000, s. 267)- şeklinde yaptığı eleştiriler oldukça sert gelebilir ama kabul etmek gerekir ki bir parça haklılık payı da olan söylemlerdir. Tolstoy, bunlarla da yetinmemiş, bu sözleri söylediği zamanla kıyasladığımızda günümüze çok daha uygun düşen bir saptama da ortaya koymuştur. "Çağımızın ve çevremizin sanatı bir fahişe olmuştur ve bu karşılaştırma, en küçük ayrıntısına kadar doğruluk taşır. O fahişe gibi, bu sanat belirli zamanlarla sınırlı değildir. Onun gibi her zaman süslüdür, onun gibi her zaman satılabilirdir ve onun gibi baştan çıkarıcı ve mahvedicidir" (Tolstoy, 2000, s. 348).

Bazı açılardan Tolstoy’a hak veriyor olsak da kendisinin taklit sanatı öğretiyorlar diye yok saymaya çalıştığı sanat akademilerinin aslında, eğitim yoluyla sanatçı adaylarını taklit sanattan korudukları gerçeğini göz ardı etmiş oluruz. Şurası çok açık ki; geçmiş sanatın ne olduğu konusunda fikri olmayan bireyler, ürettikleri her çalışmayı, sanat eseri zannetmek gibi bir yanılgı içinde olabilirler. Sanat eğitimi kurumlarının bir işe yaramadıkları yani öğrencilere, yapmaları gereken şeyleri tam olarak öğretemediklerini varsaysak bile; en azından bu kurumların öğrencileri nelerden uzak durmaları gerektiği konusunda bir işlevi yerine getirdiklerini de kabul etmeliyiz. Tamamen özgün eserler yaratabilmeye odaklanmak, her anlamda kulağa hoş gelen ve idealist düşünceyle de tam uyumlu bir görüntü veriyor olsa da aynı zamanda, 'Sanatçı, taklitçi değil, özgün olmalıdır' ifadesi aslında tam bir paradoksa sebep olur. Özgünlük, hemen her zaman, "yeni, öncü, taklit olmayan, biricik, orjinal” ve benzeri sözcüklerle ifade edilmiştir. Demokles'in Kılıcı gibi, sanatçının ensesinde hissettiği bu dayatmacı maddeler anlam olarak sanat idealizmine uygun düşüyor olabilir ancak sanatçının 
işini zorlaştırdığı da kabul edilmelidir. Yeni bir şeyler üretebilmek, en basitinden taklitten kaçınmayı gerektirir ve bu da ancak, sanatçının geçmişte olup bitenlerden haberdar olmasıyla mümkün olabilir.

Geçmiş sanatı taklitten kaçınmak; özgünlük derken özgürlüğünden olmak, sanatçının üretkenliğinin önündeki en önemli engel haline gelebilir. Tamamen orjinal olmayı hedefleyen sanatçı, farkında olmadan kendini dar bir alanda sıkışmışlık hissi içinde bulabilir ki; bu en basitinden o kişiyi inancını ve üretme hevesini kaybetme durumuyla karşı karşıya getirebilir. Peki bir eserin özgün olup olmadığını saptamak kolaymı? Aslında hiç değil çünkü belirleyici binlerce faktör olduğu, bunların da farklı koşullara bağlı olarak değişkenlik gösterdiği bu koşullarda, bu kriterleri sağlıklı bir şekilde saptamak nerdeyse olanaksızdır.

\section{8. ŞÖHRETIN SANATA ETKİSI}

Henüz hayatta iken resimleri sayesinde şöhret ve para sahibi olmuş Claude Monet (1840-1926) (Res. 4) ve Pablo Picasso (1881-1973) (Res. 5) gibi ressamlar, yaşarken hiç resim satmamış olsalardı; ne bu kadar çok iş üretebilir ne de biçim anlayışlarını bu kadar geliştirmiş olurlardı. Yaşadığı dönemde Monet de çok iyi kazanan ve saygı duyulan bir sanatçı olmasına rağmen; Picasso, popülarite konusunda bunun çok ötesinde ayrıcalıklı bir yer edinmiş ve 20 . Yüzyılın 2. Yarısından itibaren örneklerini bolca görmeye alıştığımız 'Pop Star Sanatçı' türünün de ilk örneği olmuştur. Etrafını çevrelemiş hayran kitlesi, peşinden ayrılmayan basın mensupları ve foto muhabirleri, resimlerini satın almak için bekleşen koleksiyonerler ve tabii hayatına girmiş kadınlar; daha önce bir sanatçının bu yoğunlukta karşılaşmadığı şeylerdi. Bunların hepsini düşündüğümüzde, sanat camiasında magazin kültürü onun sayesinde oluşmuştur demek hiç yanlış olmayacaktır.

Resim 4: Claude Monet, Waterlillies, 89x92cm, 1904

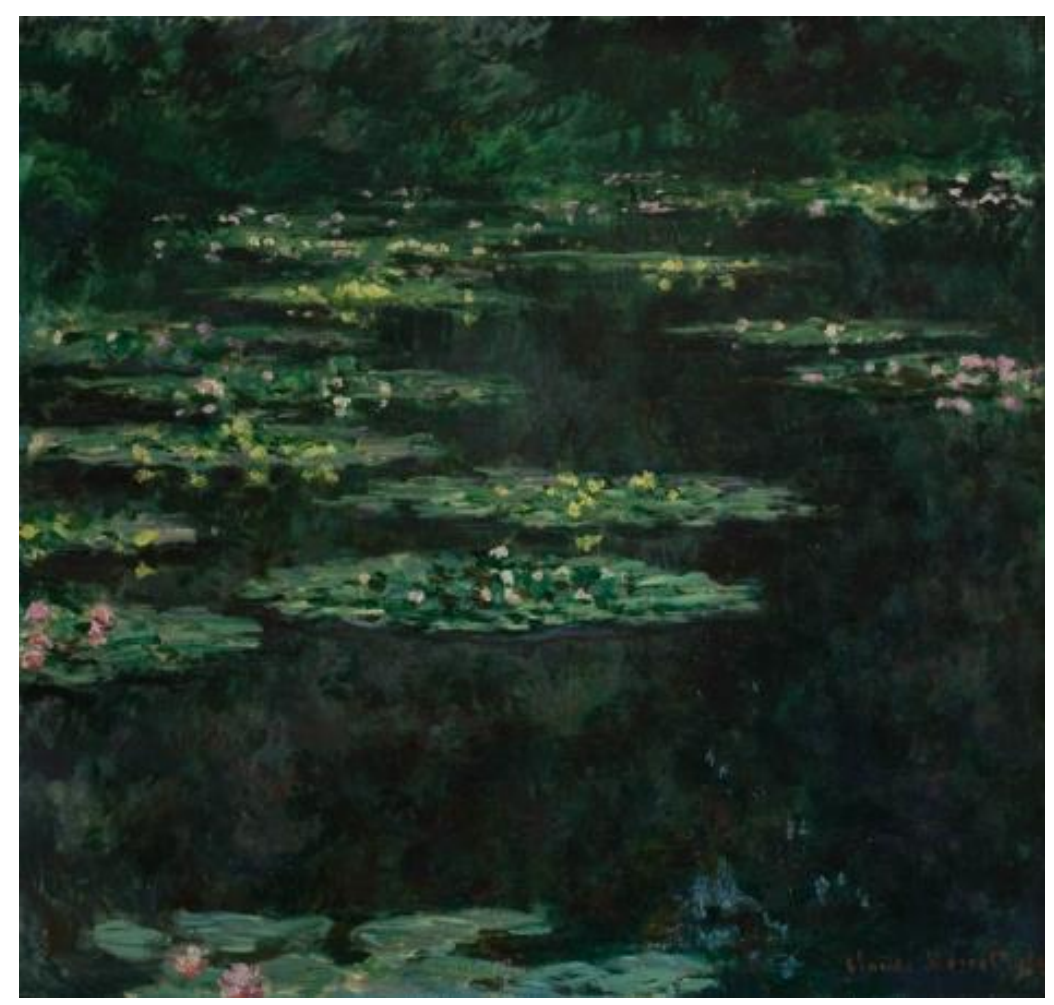


Resim 5: Pablo Picasso, Large Bather, 182x101cm, 1921

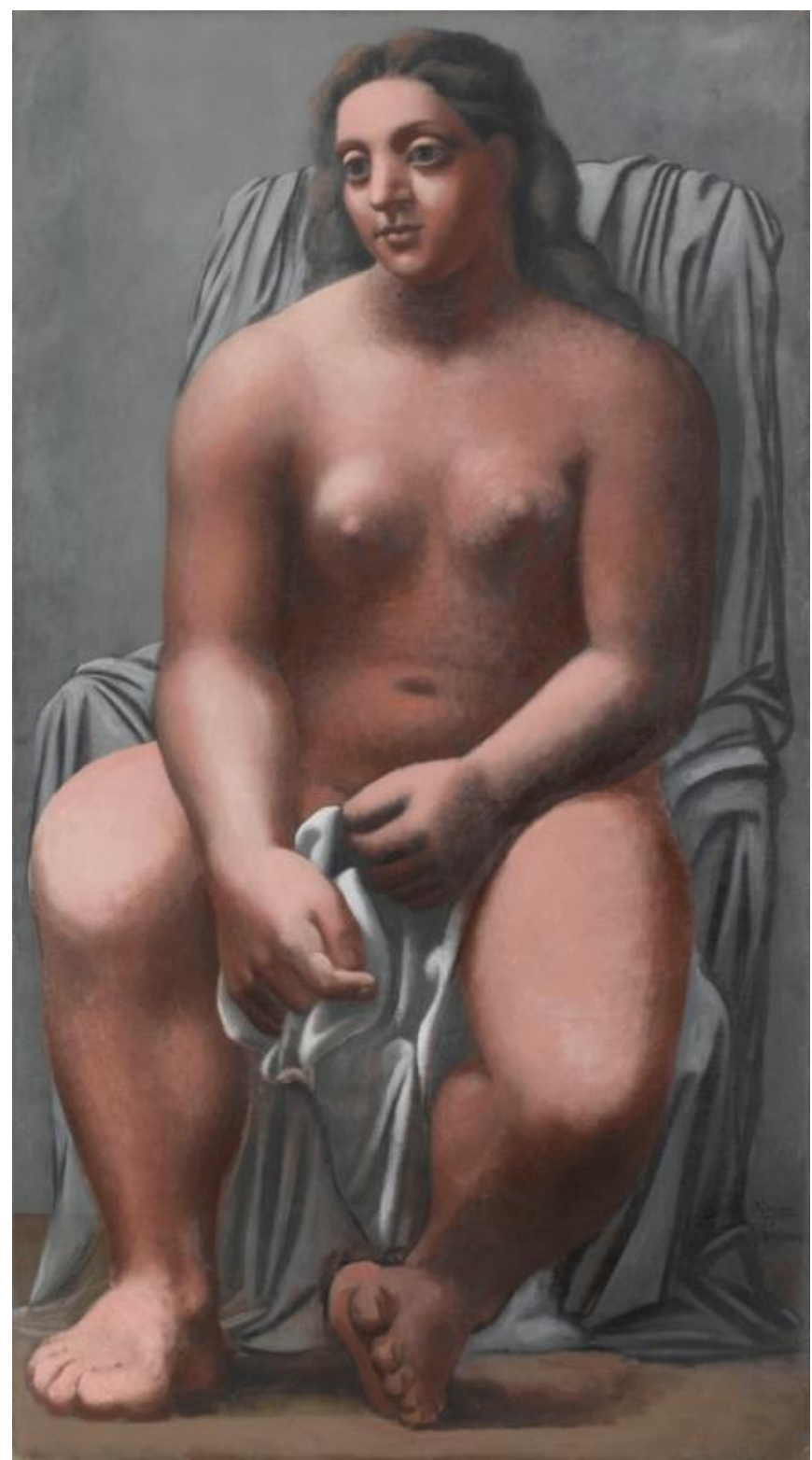

Bütün bu tanınmışlık ve eserlerinin satılıyor olması, Picasso'nun sanatsal üretimine büyük ivme kazandırmış, olasılıkla en çok resmini de bu dönemde yapmıştır. Popülaritesinin artmasıyla birlikte çok daha rahatlamış; hissettiği şımarıkça özgüven sayesinde, belki de ilk kez, gerçek anlamda özgürleşmiştir. Müsvedde kağıtlar, restoranlardaki tabak çanak ve hatta peçetelerin üzerine öylesine yaptığı karalamalar bile kapış kapış giderken, bunun Picasso'nun sanatsal tavrına etkisi olmayacağını düşünmek çok da gerçekçi olmayacaktır.

Sanatçının son dönem çalışmalarını, daha önceki analitik kübist dönemiyle (Özellikle de Guernica-1937; Res. 6) kıyasladığımızda, yeterince güçlü ve ağırlığı olan işler değilmiş gibi görünebilirler. Daha yüzeyci bir tavırda çok daha canlı renkler, şematik ve biraz da alaycı bir anlayışıyla kullanılmaya başlanmış; kasvetten uzak, farklı bir enerjiyle resim yapan bir Picasso ortaya çıkmıştır. 
Resim 6: Pablo Picasso Guernica, 3,49 m x 7,77 m, 1937

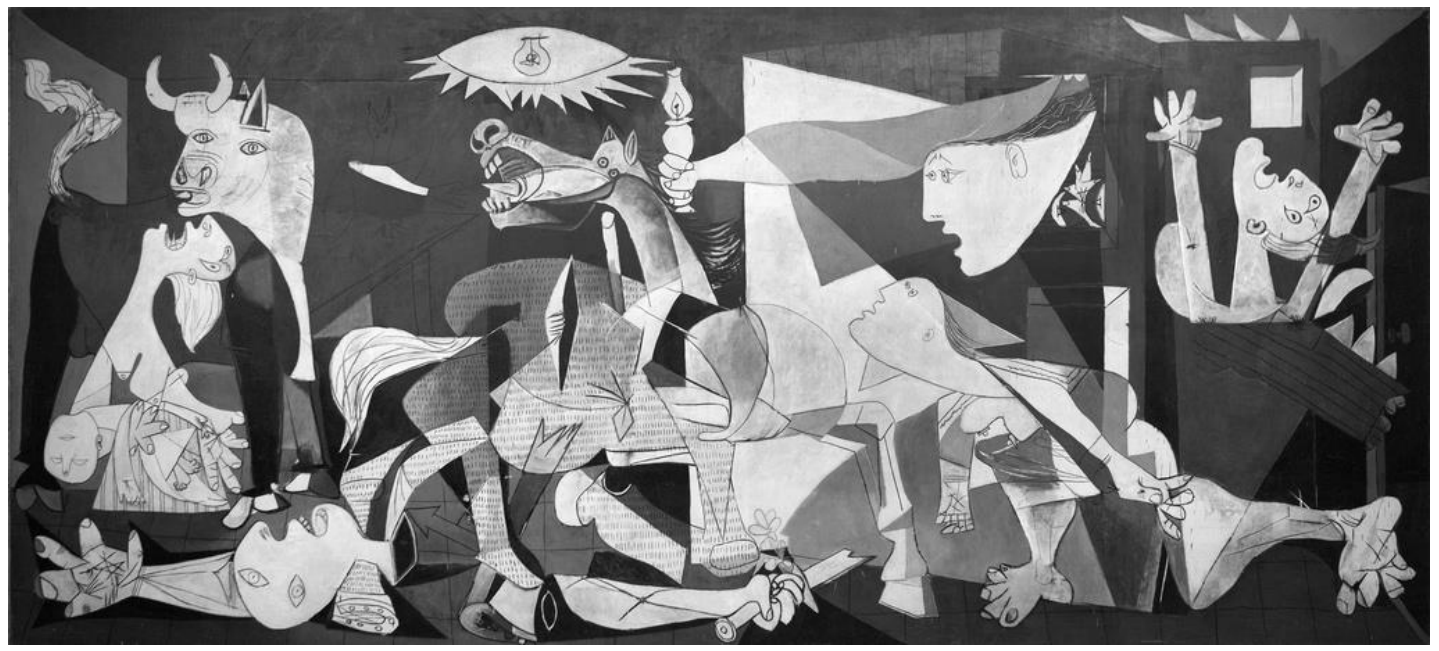

Resim 7: Pablo Picasso, Rembrandt Figure and Eros, 162x130cm, 1969

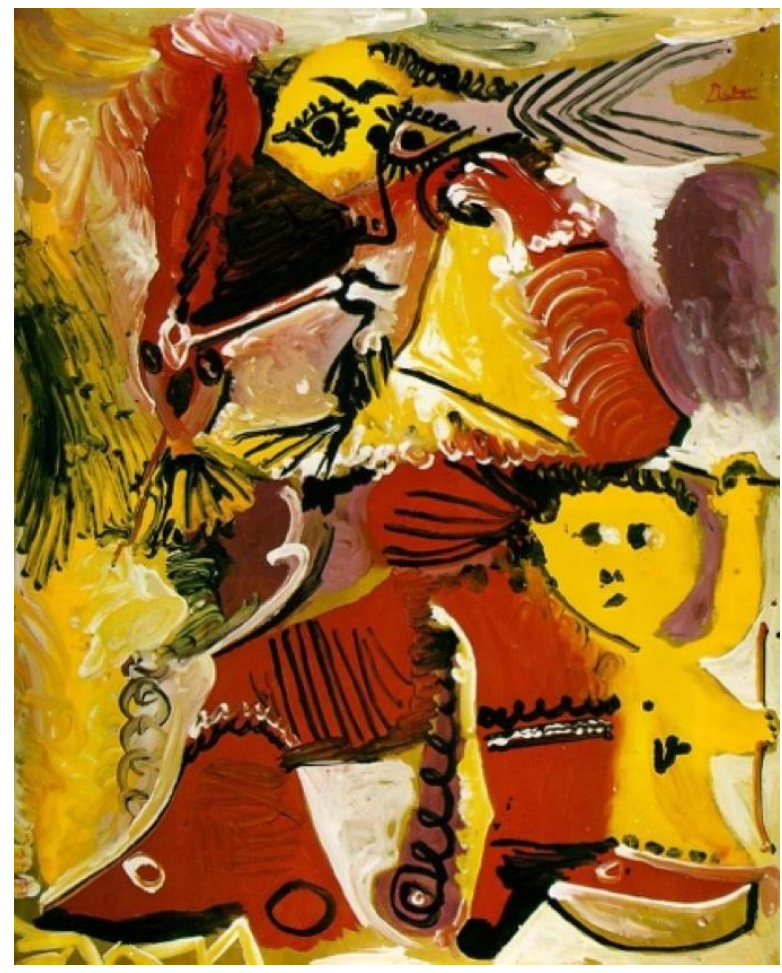

Ölümüne kadarki bu son dönemini biraz hafife alma eğiliminde olsak da bir başka açıdan olaya bakmayı denediğimizde, Picasso'nun, belki de hayatında ilk kez, hiç baskı altında kalmadan ve içinden geldiği gibi resim yapmış olabileceği gerçeğini de gözardı edemeyiz. Şöhret ve paranın, sanatçılar üzerindeki etkisi ve sanatın da buna bağlı olarak şekilleniyor olması aslında çok yeni bir tartışma konusu değildir. Olasılıkla "belki de her zaman böyleydi" diyebileceğimiz bu konuyu gözümüze sokan Andy Warhol (Res. 8) olmuştur.

Donald Kuspit, Warhol'un sebep olduğu ya da bir başka deyişle ifşa ettiği bu gerçekliği ve bunun günümüz sanatına etkisini şöyle açıklamıştır:

Sanat, Warhol'un sanatın gerçek çıkarlarını açığa vurması nedeniyle büyük bir bedel ödemeye devam etmektedir. Kendini en yüksek parayı verene satmıştır ki bu durum ne satacağı 
konusunda belirsizlik içinde olduğunu gösterir. Satacağı şeyler en çok paraya sahip olanların almak isteyeceği şeyler oldukları için değerliyse o zaman sahip olduğu tek değer onların parasından gelen değerdir ki bu da kendi değerine inanmadığı anlamına gelir. İş ve eğlencenin bize eşsiz değer diye bir şey olmadığını gösterdiği bir toplumda zaten sanat nasıl olur da eşsiz bir değere sahip olabilir ki? (Kuspit, 2006, s. 165).

Resim 8: Andy Warhol, Skull, 192.4 x 96.5 cm, ipek-baskı, 1976

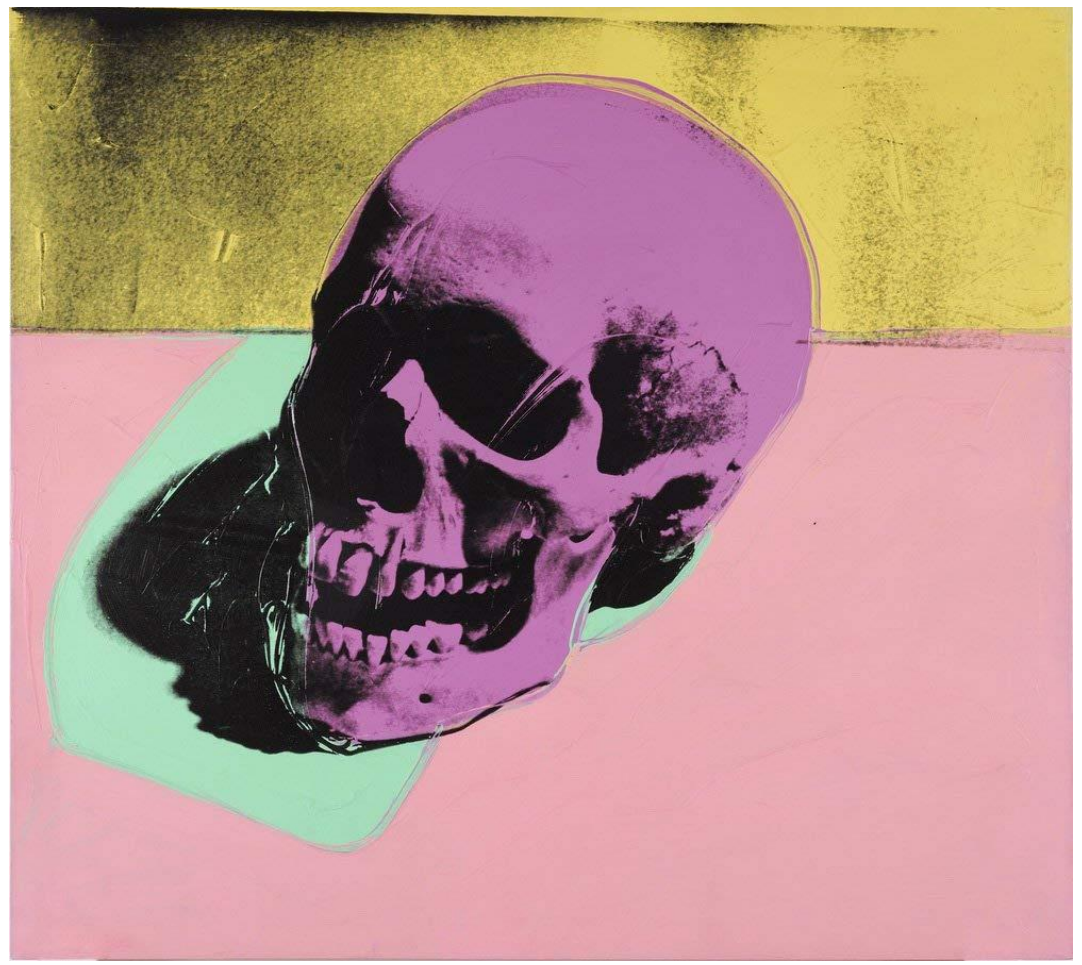

Yine Kuspit'e göre, "Kapitalizm büyük bir simyasal mucize gerçekleştirmiştir, çünkü sanatı paraya dönüştürerek sanatın, sonsuzluk adı verilen o nihai maddenin dünya üzerindeki temsilcisi olma rolünü geçersiz kılmıştır. İçinde yaşadığımız mahcubiyetten uzak materyalist döneme kadar, sanat dünya üzerinde sonsuzluğa en çok yaklaşan şey olmuştu, zaten kimi zaman "sonsuz şimdi" olarak da anılmasının nedeni budur" (Kuspit, 2006, s. 161).

\section{SONUÇ}

Sanatın ne olduğu, sanatçı olmanın insanlar tarafından nasıl algılandığı konusu hep çok karmaşık sebeplere bağlı olarak tanımlanmaya çalışılmıştır. Geçmiş dönemlerden daha fazla materyalist bir yaşam şekli içinde olduğumuz bu çağda, sanatın ve sanatla uğraşan kişilerin biraz hafife alındığı ve yüksek getirisi olan iş kollarıyla kıyaslandığında daha alt seviyede değerlendirildikleri doğrudur. Hiç azımsanmayacak bu gerçekliği bir yönüyle kabul ediyor olsak da; sanatın sürprizlere açı gizemli yanı ya da ulaşılamaz bir yücelik hissi oluşturan çağrışımları sebebiyle aslında genel olarak bir çok şeyin üzerinde konumlanmıştır. Hakkında ne söylenirse söylensin, sanata olan ilgi hiçbir zaman kaybolmamış; insanlık tarihi boyunca çok güçlü bir ifade aracı olarak benimsenmiş ve yüceltilmiştir.

Sanata ilgi muhakkak ki çok farklı sebeplerle oluşabilir. Bu itibarla sadece sanatçılar değil, genç sanatçı adayları açısından da öncelikli olan şeyin; maddi çıkarlar değil, peşinden gitmeyi hayal ettikleri idealleri olduğunu kabul etmeliyiz. Şüphesiz, bütün sanatçılar; eser üretmek dışında başka bir iş yapmak zorunda kalmadan, hayatını sürdürebiliyor olmayı tercih eder çünkü bu durumun sağlayacağı tatmin duygusu, özellikle de motive edici yanıyla hayati 
derecede önemlidir. Maddi çıkar peşinde olmak, rahatlıkla söylenebilir ki sanata soyunan hiç kimsenin önceliği değildir. Paraya dönüşmediği ya da dönüşme ihtimali olmadığ1 sürece verimli bir üretim süreci de olamayacaktır. Kabul etmek gerekir ki, en çok üretim yapanlar, çoğunlukla en çok satanlardır ve bu üretim artışı da hemen her zaman yapıtları satılmaya başladıktan sonraki döneme tekabül eder. Sanat eserlerinin satılıyor olması birçokları için kabul edilebilir bir şey olmayabilir ama bunu yapılan işin değerini azaltan değil, aksine geliştirici yönüyle kabul etmek daha doğru olacaktır. 


\section{KAYNAKÇA}

FISCHER, E. (1968). Sanatın Gerekliliği, De Yayınevi, İstanbul

KUSPIT, D. (2006). Sanatın Sonu, Metis Yayınları, İstanbul

LYNTON, N. (1982). Modern Sanatın Öyküsü, Remzi Kitabevi, İstanbul

READ, H. (1981). Sanat ve Toplum, Ümran Yayınevi, İstanbul

TOLSTOY, L. (2000). Sanat Nedir? Şule Yayınevi, İstanbul

\section{Resim Kaynakları}

Resim 1. Lascaux mağarası M.Ö. 15000

https://indigodergisi.com/2014/08/varolus-ve-sanat-1/ Alındiğı tarih: 02.02.2019

Resim 2. Kariye Müzesi, 14. yy.---https://istanbul.ktb.gov.tr/TR-202454/kariyemuzesi.htmlxLzFlL0xhc2NhdXhfcGFpbnRpbmcuanBn - Alındığı tarih: 22.02.2019

Resim 3. https://resimbiterken.wordpress.com/2014/10/06/vincent-van-goghun-portait-of-drgachet-eseri/_Alındığı tarih: 04.02.2019

Resim 4. http://www.muma-lehavre.fr/en/collections/artworks-incontext/impressionism/monet-Waterlilies. Alındığı tarih: 04.20.2019

Resim 5. https://www.musee-orangerie.fr/en/artwork/large-bather. Alındığ tarih: 04.20.2019

Resim 6. https://resimbiterken.files.wordpress.com/2014/06/guernica_all.jpg Alındığı tarih: 08.20.2019

Resim 7. https://www.google.com.tr/search?q=picasso+remrandesque+figur+and+cupid

Resim 8. https://www.amazon.com/Berkin-Arts-Warhol-Paintings-

Reproduction/dp/B076PD2PFS. Alındığı tarih: 08.20.2019 